Journal of Social Sciences 8 (2): 170-176, 2012

ISSN 1549-3652

(C) 2012 Science Publications

\title{
Shakespeare and Literacy: A Case Study in a Primary Classroom
}

\author{
George Belliveau \\ Department of Language and Literacy, Faculty of Education, \\ University of British Columbia, 2125 Main Mall Vancouver, BC V6T 1Z4, Canada
}

\begin{abstract}
Problem statement: Childhood is an integral time for literacy development and the aim of this article is to closely examine what pedagogical strategies were most effective to promote literacy learning with a group of six to nine year old children. This case study investigates how the use of specific literacy and drama-based strategies prepared and stimulated young children's understanding and appreciation of a Shakespeare play. Approach: The study was conducted over a period of three months in a multi-age Montessori primary classroom in Vancouver, Canada. Over 600 writing samples from the class of 22 children were analyzed. Eight classroom observations by the author and another researcher were documented, using field notes, still photo images and video. Interviews with the teacher, parents and children were undertaken and two years after the study, a focus group was conducted with eight of the original children who had participated in the initial research. Using a qualitative research approach, the data was analyzed in search of recurring patterns and themes that highlighted literacy strategies where children's understanding and engagement with Shakespeare was most effective. Results and Conclusion: It was observed that five particular writing and drawing strategies (word wall, journal, character masks, letters and newspaper) allowed the children to develop a greater understanding and appreciation of Shakespeare's work. The above literacy strategies fostered vocabulary development, understanding of plot and character motivations and the ability for the children to rehearse and perform the Shakespeare play for their peers and family. Member checking with a randomly selected group of children two years later and written feedback from parents confirmed key learning outcomes that occurred during the study.
\end{abstract}

Key words: Shakespeare, pedagogical strategies, drama, children, learning

\section{INTRODUCTION}

If I had to choose one reason why Shakespeare was valuable for my [seven-year-old] daughter ... I think I would say ... the worldliness she gained by learning Shakespeare. Why learn about Columbus? Why learn about the Black plague? Why know a Beatles song when you hear it? You should just know these things, because even if you don't care about them directly, they affect the world around you (Celia, interview, June 23, 2009).

This article examines a primary class' engagement with a Shakespeare play through the teacher's use of specific literacy and drama-based approaches. The research builds on work conducted by the Royal Shakespeare Company (RSC), where scholars are studying what benefits might be gained when young children are introduced to Shakespeare. The RSC study discovered that Shakespeare should be taught early, as children four or five years old are more "fearless" and "they are used to trying out new language". Like the RSC research findings, this case study suggests that young children are not intimidated by Shakespeare, in fact most of them become highly engaged with the rich and playful language, the stories and the complex characters. This engagement with Shakespeare at an early age exposes students to a worldliness, a cultural literacy (Hirsch et al., 1988) to be built upon throughout their education and lives. Shakespeare's plays offer a bridge to discover and discuss some of the great questions in life. As the most studied writer and produced playwright in the world, with over 80 languages in which his plays have been translated, this early exposure to Shakespeare allows children to immerse themselves in rich literature and complex ideas at an early age. The research in this article explores what pedagogical strategies might be most effective to introduce children to Shakespeare.

\section{MATERIALS AND METHODS}

This case study focuses on one teacher, Mrs. B. and her primary class during a three-month period, AprilJune 2009, while they explored Shakespeare's play Much Ado about Nothing. (Mrs. B. is a pseudonym as are all student and parent names referred to in this article.) The focus of this article is part of a larger fouryear research project where four teachers, including Mrs. 


\section{J. Social Sci., 8 (2): 170-176, 2012}

B., led their classes in exploring and performing adapted versions of Shakespeare's comedies (2008-2011). The research for this article took place in a multi-age Montessori primary classroom with children six to nine years old, in a Vancouver, Canada public school.

A case study involves the collection and presentation of specific information gathered in a natural setting, most often about a particular participant or a small group (Yin, 2009). As such, this approach to research is particularly well suited to share the complex literacy learning that took place between Mrs. B. and her class while they engaged with Shakespeare. Case studies combine a range of data sources including but not limited to direct observation, interviews and collections of writing samples (Eisner and Peshkin, 1990).

Collectively the 22 children in Mrs. B.'s class created over 600 pieces of reflective and creative writing/drawing during their work on Much Ado about Nothing through journals, newspaper writing, response leaves and letters. Eight parents, along with Mrs. B., participated in semi-structured interviews. Focus groups, formal and informal, were held with the children during the project and once again two years later in February 2011. Other research artifacts include Mrs. B.'s teaching plans and two adaptations of Much Ado about Nothing: Burdett and Shakespeare (2009) and Carter (2009).

The research used a phenomenological approach, seeking to describe what happened during the children's literacy engagement with Shakespeare. Part of the objective for this study was to resist "any tendency toward constructing a predetermined set of fixed procedures, techniques and concepts that would rule-govern the research project" (Manen, 1990). As such, the project did not begin with a set hypothesis, or with the intent of seeking specific quantitative findings. Although the data points to positive developments in the children's writing skills, comprehension and ability for public speaking, empirical data through pre and post surveys are not discussed in this article. The findings are of a qualitative nature, identifying, describing and analyzing specific literacy strategies that enhanced the children's learning while studying Shakespeare. To insure rigor and validity, the findings are supported and analyzed through multiple data sources, including the children's, the teacher's, the parents' and the researcher's perspective.

\section{Findings:}

Five literacy strategies: At the heart of Mrs. B.'s pedagogy is that "Shakespeare is meant to be performed, spoken out loud. Children need to play, experiment with the language, stories and characters" (interview, May 22, 2009). To prepare her children for the oral and physical engagement with Shakespeare, she used a number of different literacy-based strategies.
During the data analysis, five strategies emerged as significant learning opportunities for the children, as they represent specific moments where the pedagogical approach and the student learning seemed to crystallize (Richardson, 2000). The shifting, transient and ephemeral nature of learning that occurs in primary classrooms is often difficult to name and/or place, yet by closely reading the data the literacy approaches discussed below exemplify moments where multiple learning opportunities for children came together. The five literacy-based strategies are not unfamiliar to primary educators, yet how they are interwoven in complex, non-linear and layered ways in the process of exploring and eventually performing, Shakespeare's Much Ado About Nothing with young children is unique and the focus.

Word wall: I remember the word wall! Apparel! Dress him in my apparel! I still remember that word. And I can still see some of the words on the wall during the play with our parents, because they were all over our class. I liked our word wall. (Joan, 11 years old, focus group, February 15, 2011)

Two years after the production, Joan recalled the word wall from class and how it helped her better understand some of her lines as Beatrice. A richness of exploring Shakespeare is to delve into his imagefilled words, e.g., valiant, mirth, implore, melancholy (Fig. 1). Such poetic words help define characters and set the mood. They also build children's language capacity beyond everyday words, expanding their vocabulary and grasp of language.

Children are like sponges, they are constantly acquiring language and building vocabulary and I see it as my job to expose them daily to new and rich language (Mrs. B., interview, May 22, 2009).

The word wall was initiated on the first day that Mrs. B. and her class started work on Shakespeare. As she read Burdett's version of Much Ado about Nothing to her class, she stopped and paused to clarify dialogue and words that were potentially not familiar to her students. These words were placed on yellow cue cards, along with a brief definition and/or synonyms and then added to the word wall. Words such as 'valiant,' meaning brave, showing courage, were placed on the wall as a helpful reminder. The new vocabulary became part of the students' spelling program to bring Shakespeare's language further into their curricular routine. As well, the word wall was divided with columns for verbs, another for nouns and a third for adjectives and adverbs, allowing the children to begin to identify the parts of a sentence. 


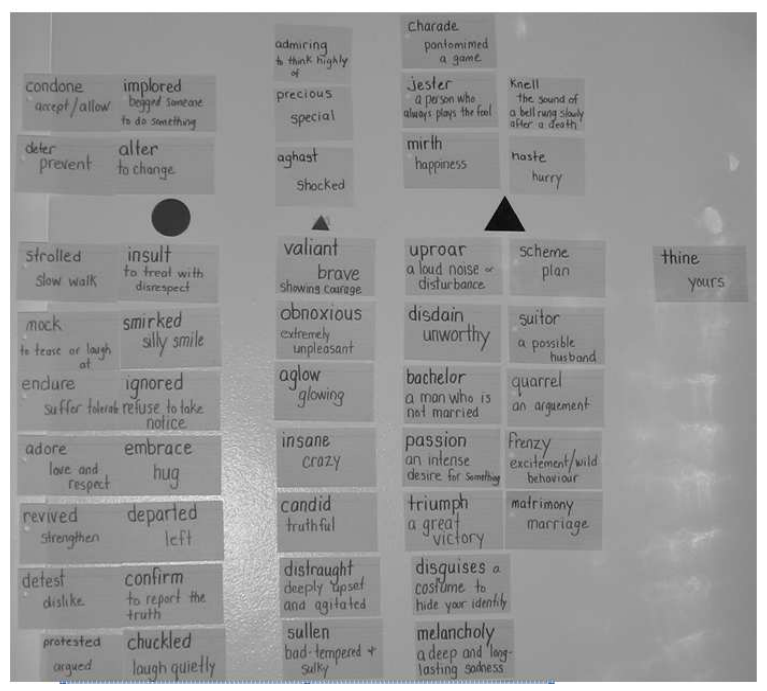

Fig. 1: Word wall

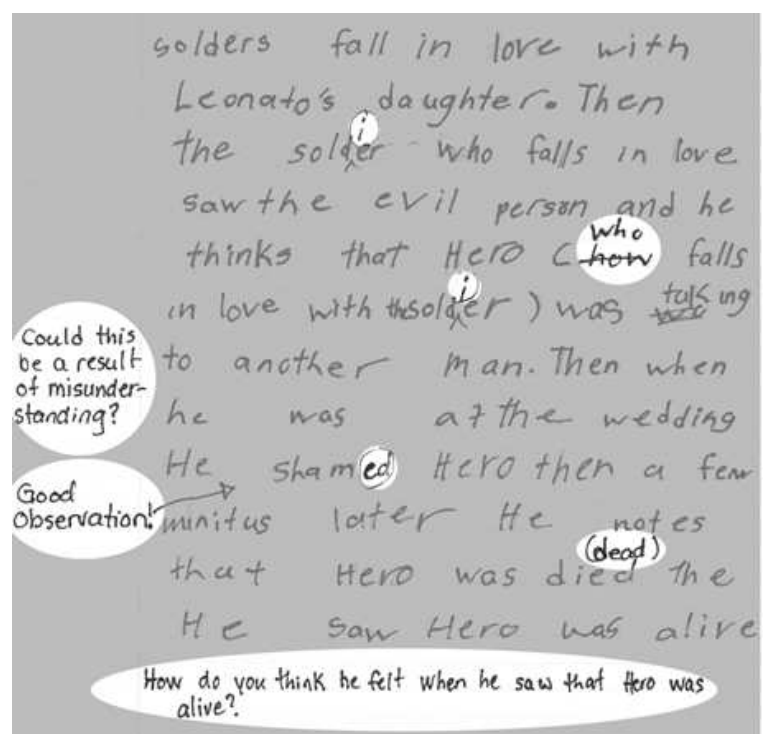

Fig. 2: Part of Kate's journal entry with comments from Mrs. B.

The children showed no signs of being intimidated by Shakespeare's words, in fact they embraced them and found various ways to make them their own:

At home ... she sometimes used Shakespearean type language in ordinary situations, surprising my husband and I at the dinner table. She really enjoyed the ongoing nature of the play ... on many different levels. It was a great experience for her and for the whole family. (Jannika, interview, June 23, 2009)
Jannika went on to share in the interview how her daughter, a struggling reader, decided on her own to make cue cards with key words to help her memorize her Don Pedro lines while rehearsing Much Ado About Nothing.

Journal: Comedies don't necessarily have to be all funny, 'cause Hero almost dies, but then doesn't. Comedies just end with weddings, with everyone happy, except Don Jon, but he's never happy. (Maddie's journal, 8 years old, May 15, 2009)

Journaling was ongoing throughout the research project, yet it was used more consistently at the beginning. It offered the children an opportunity to write and visually draw their impressions of Mrs. B.'s readings from Much Ado about Nothing and the discussions that ensued in class. Most often it was a place to summarize the events, but they could also ask questions, fictionalize and extend the plotline. Mrs. B. gave prompts for writing that included imagining and predicting: i.e., write about Beatrice and Benedict's previous encounters, before the play begins? Why do you think Don Jon is so evil? What might have led to this? Might he get caught? The writing and images created by the children provided an engagement with the story, a curiosity as to what might happen. The chorus of "Can we keep reading Mrs. B.?" frequently heard in class appeared in their journals with references to, "I wonder what will happen next" in their writing. Mrs. B.'s reading and responses to their journaling allowed her to check their understanding, clarify particular parts of the play and guide them in their discovery and literacy development. The entry below (Fig. 2) is an example of questions from Mrs. B. to guide the children's writing as well as encourage further thinking. This focus on encouragement and further inquiry in the journal writing, versus a total focus on correcting spelling and grammatical mistakes, stimulated many of the students to write daily and to write more than they had at any other time during the year.

In their writing, children often juxtaposed ideas from their own contemporary lives with moments from Much Ado about Nothing, bringing their prior knowledge to the work. For example, one child wrote in a journal entry about how Beatrice and Benedict reminded her of Luke Skywalker and Princess Leia's verbal battling relationship. Another example was a child's suggestion in their journal to use Miley Cyrus' "Hoedown Throwdown" song for the wedding scene "because its about a BIG celebration." In the end, the children and teacher collectively decided to incorporate Los del Rio's "Macarena" song for the wedding, as the dance and actions were more readily accessible for the children. The children in these examples were bridging references from their cultural world to Shakespeare's stories. 


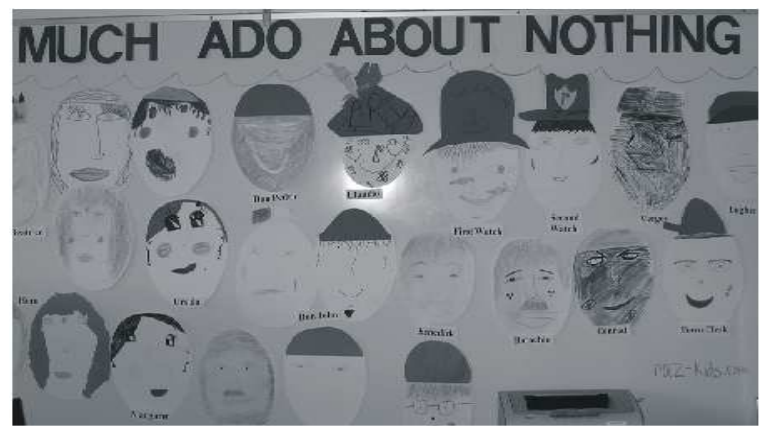

Fig. 3: Character masks

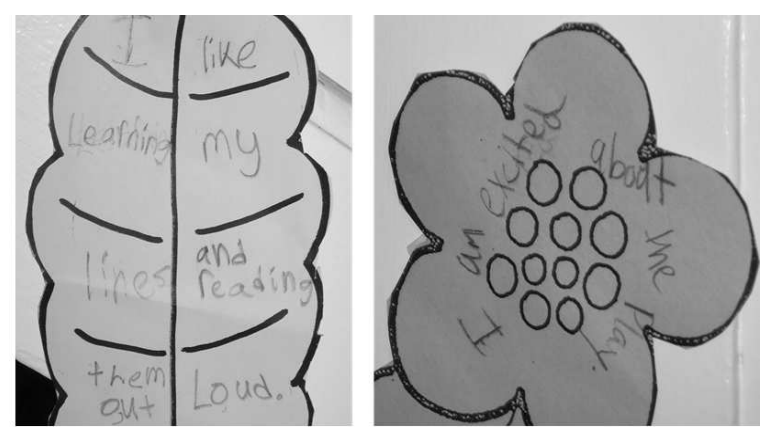

Fig. 4: Reflective leaf and flower

Character masks: With the introduction of each new character from Much Ado about Nothing, Mrs. B. would write the name with a brief description on a large piece of paper, e.g., Leonato: Governor of Messina, father of Hero. Once all the characters from the play were introduced and listed, the children engaged in creating character masks (Fig. 3).

Each child selected a character and on construction paper using oval head-like shapes they visually illustrated the facial features of their chosen character. For instance, the child who chose Conrad gave his character-mask a sly smile, mischievous eyes and a wounded cheek to illicit the character's ill repute within the play. The mask creations allowed the children to bring their understanding of the characters and as importantly the hung masks became a visual reminder of the Much Ado about Nothing characters. And similar to the word wall, the masks then figured as part of the set for the production.

The exercise of visually representing characters provided the children an opportunity to learn how specific traits, such as dark, slightly slanted eyebrows for Conrad and Don John might suggest mischievousness. This also brought forth how appearances can be stereotyped which invited valuable discussions about "prejudice and how looks may not always speak to the truth of a character or person" (Mrs. B., interview, May 22, 2009).

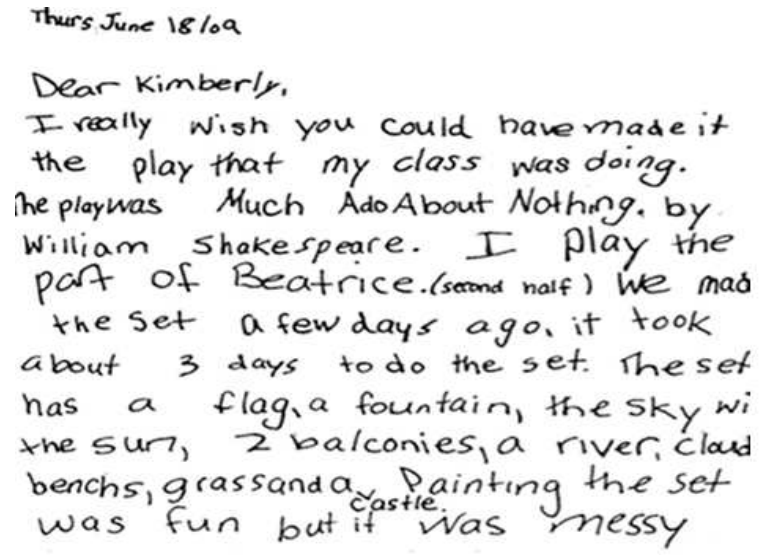

Fig. 5: First part of Sophie's reflective letter

Reflection leaves, flowers and letters: In addition to journal responses, the children were invited to write brief comments on paper-colored leaves and/or flowers (Fig. 4). These reflective pieces of writing, which included questions, comments and drawings, were then taped on the walls around the classroom, providing the beginning of the garden setting for Much Ado about Nothing. After reading a section of the story, or even during the rehearsal process, children would write what they thought about the play, their feelings about particular characters, or how rehearsals were going. As the production approached, the leaves and flowers multiplied and began to decorate Leonato's garden, anticipating, in full colors, the arrival of the soldiers returning from war at the top of the play. As data, the student writing illustrated a range of comments throughout the Shakespeare study: "I finally memorized all my lines." "I really like the wedding scene. I knew Hero didn't really die." "I'm really nervous." These written comments showcased their thinking during the process and highlighted their literacy engagement inside the décor.

A final piece of writing was asked of the children after their las performance. The task involved writing a letter to a friend or family member (Fig. 5) who did not see the production of Much Ado about Nothing. What did they miss by not seeing the play? This summative piece of reflective writing allowed the children to articulate key moments they wanted to share, what they remembered most and what they thought others should know about their experience.

\section{Newspaper:}

- I remember our newspaper. We even had ads in it about last year's play-Midsummer.

- And, oh, something about Beatrice's Pottery Sale.

- Yeah, it was fun doing that. (Tara and Clare, focus group, February 15, 2011) 


\section{The Atessína Times}

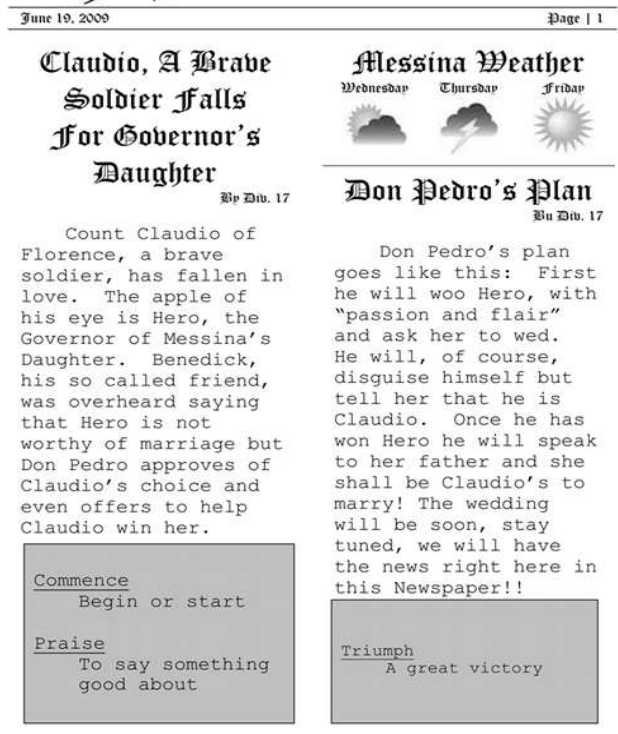

Fig. 6: Newspaper

The Messina Times (Fig. 6) was in many ways the capstone writing activity for the children and it emerged from their early journal writing. Mrs. B. paired the children to write an article depicting a significant event within the play. Each pair was asked to create a catchy headline and describe, newspaper-like, the chosen scene or moment: "Claudio, a Brave Soldier Falls for Governor's Daughter," “Don Jon's evil Plotting." Reading current newspapers, the children researched ways to catch a reader's attention. Drafts of their articles were written/re-written with Mrs. B.'s support and suggestions. The Messina Times would not be complete without pictures, so the class engaged to illustrate their articles. They also wanted to create advertisements such as "Beatrice's Pottery Sale." A word search that integrated the word wall was included. A weather forecast to trace the topsy-turvy plot of Much Ado about Nothing was on the front page. And, last but not least, the contributors were acknowledged with short biographies in the back of the ten-page issue along with the roles they were playing, thus becoming the theatre program given to friends and parents during the production. The newspaper writing brought the characters and story of Much Ado about Nothing to life for the children, as they were now the tellers of Shakespeare's play. It led naturally to the rehearsal period as they felt at ease with the content, plot line and characters.

\section{RESULTS AND DISCUSSION}

Although this article focuses mainly on the literacy components, it is important to note that findings about the entire three-month research project with the children suggested three overarching learning phases: (a) literacy, (b) drama, (c) theatre, as outlined below. Each of these phases contains overlap and they inform one another:

- Literacy: Introduce the play by exploring words, plot-line, characters, setting, historical contexts, all the while using various literacy approaches to learning such as a word wall, journal responses, reading and drawing (*literacy here is referred to in its more traditional sense, suggesting the development of reading and writing, along with speaking and listening)

- Drama: Engage in drama strategies such as hotseating, role playing, tableaux, choral speaking, to further the children's insights about characters and themes (Fels and Belliveau, 2007) for a full description of these drama-based strategies)

- Theatre: Rehearsing then performing an adapted version of Much Ado About Nothing for other classes, friends and family

Over the course of three-months the three phases were frequently interwoven, as literacy, drama and theatre approaches were utilized almost daily throughout the project. For instance, early in the process Mrs. B. wanted Shakespeare's language on the tongues of the children, so while reading the story she paused to take a close look at one of Benedict's speeches, "This can be no trick" (Carter, 2009). The soliloquy comes immediately after Benedict overhears a conversation by Don Pedro, Claudio and Leonato (Fig. 7), where the men willfully deceive Benedict into believing that Beatrice is in love with him. Mrs. B. shared what deceiving meant and what a soliloquy entails: generally alone on stage talking out loud, as if in a conversation with oneself. These words were added to the class' word wall. In their journal, children were asked to predict if they thought Benedict and Beatrice would indeed become a couple. Benedict's speech was then spoken out loud with all the children speaking in unison, using a choric approach. Then, on their feet, they moved around the space while speaking in chorus, stopping or pausing physically at the punctuation marks. Continuing with text work, half the class hid behind desks, depicting (and chorally speaking for) Don Pedro, Claudio and Leonato as they eavesdropped on Benedict, who was interpreted by the other half of the class. Bringing the language into their mouths and bodies brought the (a) literacy-based phase into (b) dramatic playing through a chorus, which was then (c) adapted for the production. 


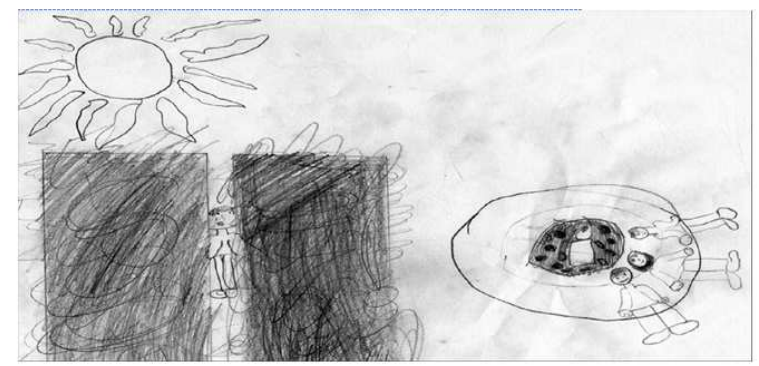

Fig. 7: Newspaper image by Ethan - Benedict hiding in bushes eavesdropping on Leonato, Claudio and Don Pedro

Previous articles and presentations about this study have highlighted the drama and theatre phases as places for meaning making and learning (Belliveau, 2009; Belliveau and Lea, 2009). However, the intent of this article is to analyze and focus on what ways the literacybased approaches became a catalyst for the children's learning through Shakespeare.

\section{CONCLUSION}

The five literacy-based strategies discussed above represent key findings from the data where children were highly engaged in their learning of Shakespeare. The children's engagement during the literacy activities suggests how this phase became foundational for the drama and theatre-based phases that were occurring either simultaneously or in the near future. The multiple writing tasks provided the children with opportunities to express their understanding of the play and became markers of their learning. The preparation that was generated by the literacy strategies allowed the children to then take greater risks as they moved towards doing drama-based activities. For instance, in doing hot-seat activities, the teacher noted how the level of questioning students would ask one another "delved deeper because they had reflected, drawn and written about various characters" (Mrs. B., interview, May 22, 2009). The hot-seat activity has a student seated in the center of the class role-playing a particular character from the play, e.g., Claudio. Other students ask the student-in-role as Claudio questions, which he or she responds to in-role:

STUDENT: Why did you speak so badly to Hero STUDENT-IN-ROLE (as Claudio): Well, I was really mad at her and I felt wronged by her

(Field notes, May 10, 2009)

The focus group comments from the children (Feb, 2011) strongly suggest that the experience of performing a Shakespeare play lives on in their memories, as they recalled the language, the set, costumes, rehearsing and performing. According to youth theatre scholar Reason (2010), a significant marker for children's learning through theatre includes an "enduring resonance as the [the work continues] to engage [them] intellectually, imaginatively or emotionally" in the future (p. 111). The foundational work generated through the literacy-based activities prepared and stimulated the children's work with Shakespeare and these written artifacts remain available for them to revisit in years to come. During the focus group two-years after the project, some of the children proudly brought their copies of the Messina Times newspaper, signed by their former classmates. Some also brought their journals and collectively they reminisced, as they leafed through their written work about their experience with Much Ado about Nothing. The re-lived memories included the work on the newspaper, the creation of the set, their costumes and most importantly the collective experience of having performed a Shakespeare play. Two of the participating students, Aidan and Elisha, sum up their experience:

AIDAN: It was like ... we were sort of a company of actors, except ... it was school ... with all the reading and writing stuff

ELISHA: And doing the set ... yeah, I remember us painting

AIDAN (pointing to his copy of the newspaper): And we had the program inside our newspaper ...

ELISAH: The one on the front page that's by me and Sam ... about Don Pedro ... and we did one of the advertisements

AIDAN: It was fun ... and learning too.

(focus group, February 15, 2011)

\section{ACKNOWLEDGEMENT}

I would like to thank the Social Sciences and Humanities Research Council of Canada for funding the research. Also, I want to sincerely thank the children for their willingness to participate in the research as well as their parents who gave consent and provided their thoughts about the project. Special thank you to the teacher, Mrs. B. for allowing the research to take place in her classroom and enabling the research team to conduct various interviews and follow-ups about the project. Finally, thank you to UBC research assistants Amanda Wager, Eva Ziltener and Graham W. Lea who respectively helped to collect and interpret some of the data for this research. G.W. Lea also shared 
his photo images for this article and was instrumental in the layout of them.

\section{REFERENCES}

Belliveau, G. and G.W. Lea, 2009. Examining an elementary class' journey with Shakespeare. International Drama in Education Research Institute. Sydney, Australia.

Belliveau, G., 2009. Elementary students and shakespeare: Inspiring community and learning. Int. J. Arts Soc., 4: 1-8.

Burdett, L. and W. Shakespeare, 2009. Much Ado about Nothing for Kids. 1st Edn., Baker and Taylor, CATS, Paw Prints, ISBN: 1442018542.

Carter, R., 2009. A Community Shakespeare Company Edition of Much Ado about Nothing. 1st Edn., iUniverse, ISBN: 1440115958 pp: 96.

Eisner, E.W. and A. Peshkin, 1990. Qualitative Inquiry in Education: The Continuing Debate. 2nd Edn., Teachers College, New York, ISBN-10: 0807730173 , pp: 387.
Fels, L. and G.A. Belliveau, 2007. Exploring Curriculum: Performative Inquiry, Role Drama and Learning. 1st Edn., Pacific Educational Press, Vancouver, ISBN-10: 9781895766844, pp: 286.

Hirsch, E.D., J.F. Kett and J.S. Trefil, 1988. Cultural Literacy: What Every American Needs to Know. 1st Edn., Vintage Books, New York, ISBN-10: 0394758439, pp: 251.

Manen, M., 1990. Researching Lived Experience: Human Science for an Action Sensitive Pedagogy. 1st Edn., State University of New York Press, Albany, New York, ISBN-10: 0791404250, pp: 202.

Reason, M., 2010. The Young Audience: Exploring And Enhancing Children's Experiences of Theatre. 1st Edn., Trentham Books, England, ISBN-10: 9781858564500, pp: 180.

Richardson, L., 2000. Writing: A Method of Inquiry. In: Handbook of Qualitative Research. 2nd Edn., Sage, Thousand Oaks, United States, pp: 923-948.

Yin, R.K., 2009. Case Study Research: Design and Methods. 4th Edn., Sage Publications, Thousand Oaks, ISBN-10: 9781412960991, pp: 219. 